\title{
Microstructure Analysis of Welded Joints after Laser Welding
}

Jozef Meško ${ }^{1}$, Andrej Zrak ${ }^{1}$, Krystian Mulczyk ${ }^{2}$, Szymon Tofil ${ }^{2}$

${ }^{1}$ Faculty of Mechanical Engineering, University of Žilina, Univerzitná 8215/1, 01026 Žilina. Slovak Republic. Email: jozef.mesko@fstroj.uniza.sk, andrejzrak@gmail.com

${ }^{2}$ Faculty of Mechatronics and Mechanical Engineering, Kielce University of Technology, Aleja 1000-lacia Panstva Polskiego 7, 25-314 Kielce. Republic of Poland,Email: kmulczyk@tu.kielce.pl, tofil@tu.kielce.pl

Titanium alloys are widely used in aerospace and automotive industries. They are used to implement some parts of machines, also in the chemical industry, power industry, arms industry, shipbuilding, in implantology and biomedical engineering. Extent of use of this material is mainly due to high corrosion resistance, especially in aggressive environments. These are materials with a low ratio of the weight in relation to the mechanical properties. That is, while maintaining the desired mechanical properties of structures made of titanium is lighter than the standard stainless steel.Unfortunately, the properties of titanium, in particular at temperatures higher than the affinity of the nitrogen and oxygen in the air, has an effect on some types of processing. In particular, the heat treatment as cutting or welding, due to the fact that the reaction of titanium and oxygen is highly exothermic. Therefore, the parts of the titanium produced in an inert atmosphere.

Keywords: Laser welding, $\mathrm{CO}_{2}$ laser, titan grade 2, microstructure

\section{Acknowledgement}

This work was supported in part by the KEGA $\check{c} .054 \check{Z} U-4 / 2012$ and VEGA č. 1/0836/13.

\section{References}

[1] ASHBY M.F., EASTERLING K.E. (1984). The transformation hardening of steel surfaces by laser beams - I. In: Hypo-eutectoid steels. Acta Metall. Vol. 32, No 11, pp. 1935-1948.

[2] DOPJERA, D., MIČIAN, M. (2014) The detection of articullary made defects in welded joint with ultrasonic defectoscopy Phased Array. In: Manufacturing Technology, Vol. 14, No. 1, pp. 12-17, ISSN 1213-2489

[3] KOŇÁR, R., MIČIAN, M., (2012). Numerical simulation of residual stresses and distortions in butt weld in simulation program Sysweld. In: Comunications: scientific letters of the University of Žilina. Vol. 14, No. 3. pp. 4954. ISSN 1335-4205. Žilina.

[4] RADEK, N., ANTOSZEWSKI, B. (2009) Influence of laser treatment on the properties of electro-spark deposited coatings. In: Kovove Materialy - Metallic Materials 47, pp. 31-38, 2009

[5] ŽMINDÁK, M. et all., (2012). Numerical simulation of contact stresses analysis with crack. In: Machine modeling and simulations 2012. pp. 321-330, Poznan, ISBN 978-83-923315-2-0

[6] NOVAK, P., ŽMINDÁK, M., PELAGIĆ, Z., (2014). High-pressure pipelines repaired by steel sleeve and epoxy composition. In: Applied mechanics and materials. Vol. 486, pp. 181-188. ISSN 1660-9336.

[7] LUKOVICS, I. MALACHOVÁ, M. (2007). Use of Laser in Engineering. In: Manufacturing Technology. Vol. 12. No. 13. pp. 26-31. ISSN 1213-2489

[8] KOŇÁR, R., MIČIAN, M. (2014) Non-destructive testing of welds in gas pipelines repair with Phased Array ultrasonic technique. In: Manufacturing Technology, Vol. 14, No. 1, pp. 42-47, ISSN 1213-2489 